\title{
Patterns of photosynthesis in 18 species of intertidal macroalgae from southern Chile
}

\author{
Iván Gómez ${ }^{1, *}$, Félix López-Figueroa ${ }^{2}$, Nancy Ulloa ${ }^{1}$, Viviana Morales ${ }^{1}$, \\ Charlotte Lovengreen ${ }^{3}$, Pirjo Huovinen ${ }^{1,5}$, Susan Hess ${ }^{4}$ \\ ${ }^{1}$ Instituto de Biología Marina, ${ }^{3}$ Instituto de Física, and ${ }^{4}$ Instituto de Química, Universidad Austral de Chile, Casilla 567, \\ Valdivia, Chile \\ ${ }^{2}$ Departamento de Ecología, Universidad de Málaga, Teatinos s/n, 29071 Málaga, Spain \\ ${ }^{5}$ Present address: Department of Biological and Environmental Science, University of Jyväskylä, PO Box 35, \\ 40500 Jyväskylä, Finland
}

\begin{abstract}
Photosynthetic characteristics of 18 macroalgal species, measured as chlorophyll a ( $\mathrm{chl} \mathrm{a)} \mathrm{fluorescence} \mathrm{of} \mathrm{photosystem} \mathrm{II} \mathrm{(PSII),} \mathrm{pigment} \mathrm{contents} \mathrm{and} \mathrm{susceptibility} \mathrm{of} \mathrm{photosynthesis} \mathrm{to}$ solar radiation, were studied in the field in southern Chile (Niebla, Valdivia) during mid-summer. Photosynthesis versus irradiance curves indicated that algae exhibited sun-adapted characteristics, with saturating points for photosynthesis $\left(E_{\mathrm{k}}\right)$ ranging between 50 and $400 \mu \mathrm{mol}$ photon $\mathrm{m}^{-2} \mathrm{~s}^{-1}$. Under the solar radiation conditions that prevailed during the study period at this locality (daily doses of photosynthetically active radiation, PAR, close to $14000 \mathrm{~kJ} \mathrm{~m}^{-2} \mathrm{~d}^{-1}$, with instantaneous irradiances exceeding $2000 \mu \mathrm{mol}$ photon $\mathrm{m}^{-2} \mathrm{~s}^{-1}$ at noon), algae were light saturated for periods $\left(\mathrm{H}_{\text {sat }}\right)$ between 11 and $14 \mathrm{~h} \mathrm{~d}^{-1}$. Daily courses of optimal quantum yield $\left(F_{\mathrm{v}} / F_{\mathrm{m}}\right)$ of chl a fluorescence of PSII revealed the existence of photoinhibition of $46 \%$ at maximum relative to fluorescence measured in the morning. Similarly, the effective quantum yield $\left(\Phi_{\mathrm{PSII}}\right)$ showed a decrease at noon coinciding with the peak of solar radiation. This reduction in $\Phi_{\text {PSII }}$ was accentuated when algae were maintained in immersion for the whole measuring period; whereas, in algae measured in situ, i.e. subject to varying tidal height, chl a fluorescence decreased less. Although algae are currently exposed to very high doses of ultraviolet (UV) radiation, short-term exposures of $2.5 \mathrm{~h}$ around noon using specific cut-off filters did not result in high photoinhibition of $F_{\mathrm{v}} / F_{\mathrm{m}}$ (rates $<25 \%$ ), reinforcing the idea that these intertidal species are characterized by a marked tolerance to current solar UV radiation. Differences in the rates of photoinhibition of photosynthesis as well as in the photosynthetic characteristics were not related to functional-form group (e.g. thin vs thick morphs). Instead, the photosynthetic performance of algae was determined by their position in the shore: algae growing at mid-/infra-littoral zones had lower $E_{\mathrm{k}}$ and lower photoinhibition than algae from upper locations.
\end{abstract}

KEY WORDS: Macroalgae · Photoinhibition · Photosynthesis · Southern Chile · UV radiation Resale or republication not permitted without written consent of the publisher

\section{INTRODUCTION}

The marine flora of the southern coast of the southeast Pacific Ocean comprises unique communities characterized by the presence of endemic groups inter-mixed with sub-tropical and sub-Antarctic components (Santelices 1980, Lüning 1990). Some species are particularly abundant and subjected to intense commercial exploitation or are harvested for local con- sumption (SERNAPESCA 2001). In terms of their population dynamics and phenology, many of these organisms have been relatively well studied (Westermeier \& Möller 1990, Gómez \& Westermeier 1991, Westermeier et al. 1994). However, less attention has been given to aspects related to, e.g. ecophysiological performance, light utilization under changing solar radiation conditions or estimations of primary productivity. In coastal regions south of $40^{\circ} \mathrm{S}$, environmental conditions are 
strongly influenced by climatic (e.g. 'El Niño' events), oceanographic (e.g. the Humboldt current) processes and more recently by global atmospheric phenomena (e.g. stratospheric ozone depletion), which alone or in combination result in complex and changing physiological scenarios, particularly for algae inhabiting shallow and intertidal sites.

A variety of evidence in the recent literature indicates that seaweeds are sensitive to enhanced solar radiation, including short wavelengths (UV-B, 280 to $315 \mathrm{~nm}$ ), and its effects may be expressed as photoinhibition of photosynthesis (Hanelt et al. 1993, Dring et al. 1996b, Figueroa et al. 1997, Bischof et al. 1998), DNA damage (Pakker et al. 2000a,b, Wiencke et al. 2000, van de Poll et al. 2001), inhibition of the activity of enzymes involved in nutrient transport and carbon assimilation (Gómez et al. 1998, Bischof et al. 2000), and finally decreased growth (Grobe \& Murphy 1998, Aguilera et al. 1999, Altamirano et al. 2000, Pang et al. 2001). Such findings were derived from studies on species of the northern hemisphere, while southern species have been less intensively studied. Hanelt et al. (1994a) identified diverse daily patterns of photoinhibition of photosynthesis in macroalgae from Antarctica. Similarly, photoinhibition of photosynthesis could be observed in various macroalgal species from the Sydney Basin (Larkum \& Wood 1993) and Great Barrier Reef (Franklin et al. 1996) in Australia. No data on lightrelated physiological responses of macroalgae are available from Chile, whose coast-line consists of more than $5000 \mathrm{~km}$. Taking into account that during springsummer ozone-depleted air masses can reach latitudes outside the Antarctic Vortex, it is reasonable to argue that algae in this region are exposed to enhanced doses of solar UV radiation during such episodes. In fact, erythemal daily doses of UV radiation in some areas in southern Chile $\left(40^{\circ} \mathrm{S}\right)$ can become as high as $7.0 \mathrm{~kJ} \mathrm{~m}^{-2}$ (Lovengreen et al. 2000), whereas PAR doses can exceed $14000 \mathrm{~kJ} \mathrm{~m}^{-2} \mathrm{~d}^{-1}$ (this investigation). These doses are comparable to values recorded in New Zealand and Australia, and significantly higher than those measured at corresponding latitudes in the northern Hemisphere (Seckmeyer et al. 1995, McKenzie et al. 1996) or even at mid-latitudes (e.g. Mediterranean coast, Gómez et al. 1998). Thus, the implications for coastal ecology and primary production may be considerably greater than those estimated already for some ecosystems in the northern hemisphere (Bothwell et al. 1994).

In the present investigation, we examined for the first time the course of photosynthetic activity, measured as pulse amplitude modulated fluorescence, of various intertidal macroalgae during a period of high solar radiation in summer (Dec-Jan) in order to elucidate whether these naturally occurring levels of radiation cause photoinhibition or limit physiological perfor- mance. Two main questions are addressed: (1) Is there a relationship between photoinhibition of photosynthesis and morpho-functional organization (thick vs delicate algae)? and (2) does photoinhibition vary in algae inhabiting different levels along the intertidal gradient (supra- vs infralittoral)? These studies were accompanied by monitoring of solar radiation and biooptical characterization of the algae including concentrations of pigments and thallus absorptance. This initial effort represents a baseline for further research related to environmental tolerance and acclimation mechanisms of macroalgae that make a substantial contribution to the organic supply and primary productivity in this important biogeographical region.

\section{MATERIALS AND METHODS}

Study site. Eighteen species of Rhodophyta, Chlorophyta and Phaeophyta from different morpho-functional groups (Table 1) were sampled from a rocky platform in Niebla, near Valdivia (Southern Chile, $39^{\circ}$ $48^{\prime} \mathrm{S}, 73^{\circ} 14^{\prime} \mathrm{W}$ ). The intertidal system is formed by metamorphic rocky substrates with abundant crevices and ponds. Tides are semi-diurnal and maximal height during the study period (Dec-Jan 2001-2002) reached $2 \mathrm{~m}$. Macroalgal assemblages (Fig. 1) in the supralittoral are characterized by patchy formations of Porphyra columbina (sun type), which are immersed only during extremely high tide $(2 \mathrm{~m})$. In the upper midlittoral, green algae Enteromorpha intestinalis, Chaetomorpha linum and Ulva sp. can be clearly distinguished. The mid-littoral zone is dominated by species such as Ulva rigida and the red alga Mazzaella laminarioides. However, the red alga Gelidium sp. and the brown alga Petalonia fascia can also be found colonizing shaded pools and rocky crevices. In the mid-infralittoral, a well-developed belt of the kelp Macrocystis pyrifera occurs at the edges of profound crevices intermixed with the red alga Sarcothalia crispata and shade morphs of Porphyra columbina. The lower end of the platform, close to the line of extreme low tide (ELWS), is characterized by a heterogeneous group of species, mainly the red algae Ahnpheltiopsis durvillaei, Grateloupia doryphora, Callophyllis variegata, the complex of Ceramium/Polysiphonia and individuals of the brown alga Desmarestia ligulata.

Measurements and levels of solar radiation. Continuous monitoring of solar radiation conditions at Valdivia were conducted using 2 radiometers placed free of interference on the roof of the Science Faculty of the Universidad Austral, Valdivia. A GUS-511 multichannel filter radiometer (Biospherical Instruments) recorded UV and PAR irradiances every $1 \mathrm{~min}$ at 4 spectral narrow bands, 305, 320 , 340 and $380 \mathrm{~nm}$, and 
Table 1. Investigated macroalgae indicating functional-form groups (sensu Littler \& Littler 1980) and vertical distribution at Niebla, Valdivia

\begin{tabular}{|lll|}
\hline Species & Functional-form group & Intertidal zonation \\
\hline Chlorophyta & & \\
Ulva rigida C. Agardh & Sheet-like & Mid-littoral \\
Ulva costata (Howe) Hollemberg & Sheet-like & Mid-littoral (pools) \\
Chaetomorpha linum (Müller) Kützing & Filamentous & Supra-/mid-littoral \\
Enteromorpha intestinalis (Linnaeus) Link & Sheet-like (tubular) & Supra-/mid-littoral \\
Rhodophyta & & \\
Laingia hookerii (Lyall) Kylin & Thin leathery & Upper sublittoral \\
Gelidium lingulatum Kützing & Coarsely branched \\
Mazzaella laminarioides (Bory) Fredericq & Thick leathery & Mid-littoral (pools) \\
Ahnfeltiopsis durvillaei (Bory) Silva \& DeCew & Coarsely branched & Mid-littoral \\
Polysiphonia sp. & Filamentous & Infralittoral \\
Grateloupia doryphora (Montagne) Howe & Thick leathery & Infralittoral \\
Gymnogongrus furcellatus (C. Agardh) J. Agardh & Coarsely branched & Infralittoral \\
Callophyllis variegata (Bory) Kützing & Thick leathery & Mid-/infralittoral \\
Sarcothalia crispata (Bory) Leistner & Thick leathery & Infralittoral \\
Porphyra columbina Montagne (shade-type) & Sheet-like & Lower mid-littoral \\
Porphyra columbina Montagne (sun-type) & Sheet-like & Mid-littoral \\
Phaeophyta & & Supralittoral \\
Macrocystis pyrifera (Linnaeus) C. Agardh & Thick leathery \\
Petalonia fascia (Müller) Kuntze & Thin leathery \\
Desmarestia ligulata (Stackhouse) Lamouroux & Thick leathery & Infra/sublittoral \\
& & Mid-littoral (pools) \\
\hline
\end{tabular}

1 broad band (400 to $700 \mathrm{~nm})$, respectively. The spectral characteristics between 280 and $600 \mathrm{~nm}$ were monitored every 15 min using a SUV-100 spectroradiometer (Biospherical Instruments). Both instruments were intercalibrated so that instantaneous radiation records from the SUV-100 were used to calculate daily doses of UV, while PAR doses were measured using the GUS511 radiometer. The study period ( $14 \mathrm{~d}$ ) was characterized by sunny days and high irradiances of PAR and UV, with maximal instantaneous irradiances averaging $2500 \mu \mathrm{mol}$ photon $\mathrm{m}^{-2}$ for PAR and 2.2 and $77 \mathrm{~W} \mathrm{~m}^{-2}$ for UV-B (280 to $315 \mathrm{~nm}$ ) and UV-A (315 to 400), respec- tively (Table 2). Peaks of PAR higher than $3000 \mu \mathrm{mol}$ photon $\mathrm{m}^{-2} \mathrm{~s}^{-1}$ are explained by reflection episodes caused by clouds. Daily doses of PAR were similarly high peaking to values close to $14000 \mathrm{~kJ} \mathrm{~m}^{-2}$, while daily doses of UV-B and UV-A reached maximums of 50 and $1900 \mathrm{~kJ} \mathrm{~m}^{-2}$, respectively. Although cloudy episodes could enhance solar radiation instantaneously, in general, presence of clouds resulted in decreases by $40 \%$ approximately. Ozone concentrations recorded by Total Ozone Mapping Spectroradiometer (TOMS) data (http://jwocky.gsfc.nasa.gov) varied between 275 and 302 DU (Dobson Units) during the study

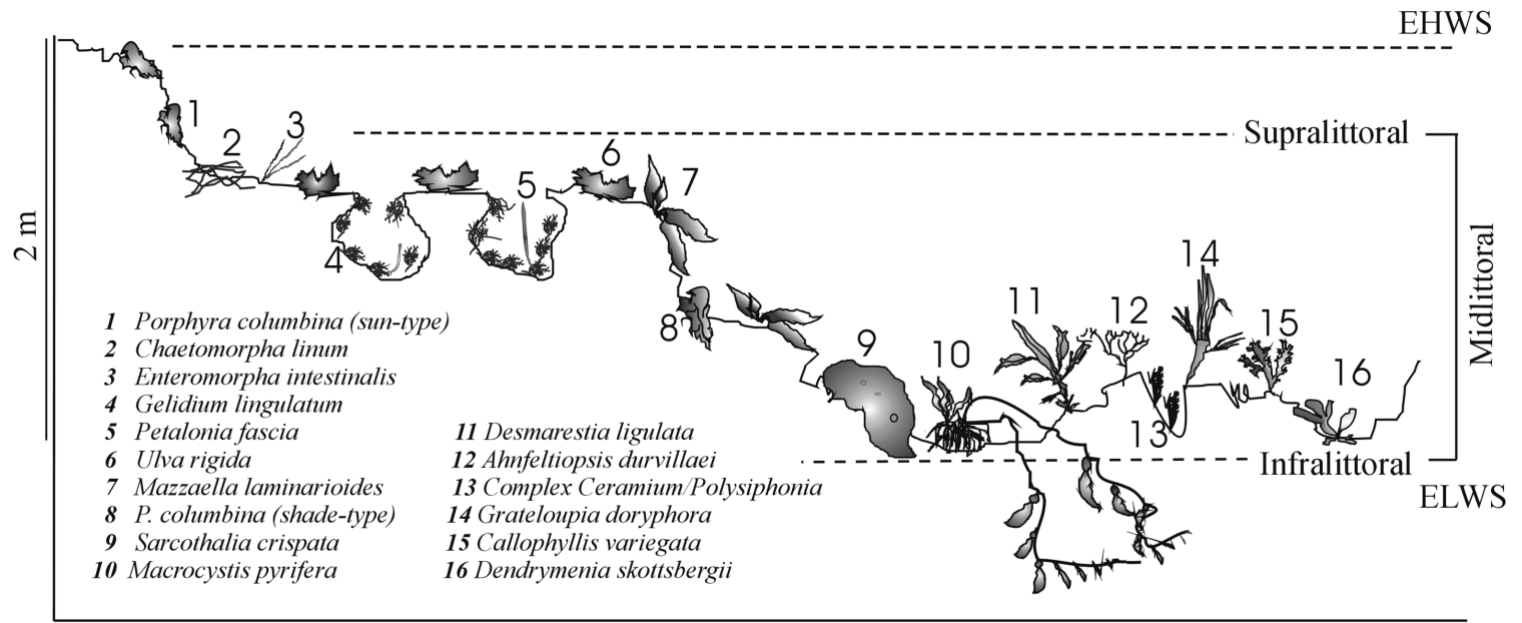

Fig. 1. Species composition and intertidal zonation at Niebla, Valdivia. EHWS/ELWS: extreme high/low water spring tide 
Table 2. Levels of solar radiation measured at Valdivia $\left(39^{\circ} 52^{\prime} \mathrm{S}, 73^{\circ} 25^{\prime} \mathrm{W}\right)$ and total ozone concentrations from TOMS data during the study period (http://jwocky.gsfc.nasa.gov)

\begin{tabular}{|c|c|c|c|c|c|c|c|}
\hline \multirow[t]{2}{*}{ Date } & \multicolumn{3}{|c|}{ Maximal quantum irradiance rate at noon } & \multicolumn{3}{|c|}{ Daily dose } & \multirow{2}{*}{$\begin{array}{c}\text { Ozone (TOMS) } \\
\text { DU }\end{array}$} \\
\hline & $\begin{array}{c}\text { UV-B } \\
\left(\mathrm{W} \mathrm{m}^{-2}\right)\end{array}$ & UV-A & $\begin{array}{c}\text { PAR } \\
\left(\mu \mathrm{mol} \mathrm{m}{ }^{-2} \mathrm{~s}^{-1}\right)\end{array}$ & UV-B & $\begin{array}{c}\text { UV-A } \\
\left(\mathrm{kJ} \mathrm{m}^{-2}\right)\end{array}$ & PAR & \\
\hline $28 \operatorname{Dec} 01^{a}$ & 2.09 & 63.13 & 2422.2 & 47.8 & 1684.5 & 14340.0 & 275.9 \\
\hline 29 Dec 01 & 1.96 & 60.41 & 2250.4 & 46.6 & 1803.3 & 14730.0 & 303.3 \\
\hline 30 Dec 01 & 2.01 & 61.42 & 2536.5 & 47.4 & 1778.0 & 14507.0 & 288.8 \\
\hline 31 Dec 01 & 1.82 & 66.44 & $2830.3^{\mathrm{b}}$ & 32.2 & 1216.4 & 9084.0 & 301.1 \\
\hline 1 Jan 02 & 2.09 & 65.53 & 2542.6 & 43.7 & 1709.2 & 12963.0 & 294.2 \\
\hline 2 Jan 02 & 2.13 & 65.38 & 2585.4 & 46.2 & 1737.5 & 13178.4 & 311.3 \\
\hline 3 Jan 02 & 1.68 & 62.03 & 2412.3 & 33.6 & 1400.0 & 10462.1 & 301.0 \\
\hline $4 \operatorname{Jan} 02^{\mathrm{a}}$ & 2.00 & 63.21 & 2261.2 & 47.1 & 1873.7 & 14820.0 & 302.4 \\
\hline 5 Jan $02^{\mathrm{a}}$ & 2.01 & 62.72 & 2262.0 & 47.5 & 1870.4 & 14830.6 & 296.1 \\
\hline $6 \mathrm{Jan} 02^{\mathrm{a}}$ & 2.12 & 63.74 & 2276.8 & 50.1 & 1886.1 & 14876.7 & 292.1 \\
\hline 7 Jan 02 & 2.17 & 79.66 & $2813.7^{b}$ & 29.4 & 1006.9 & 6410.4 & 292.1 \\
\hline 8 Jan 02 & 2.26 & 69.48 & $3139.1^{b}$ & 36.4 & 1333.1 & 9765.5 & 283.4 \\
\hline 9 Jan 02 & 2.17 & 65.41 & 2330.9 & 47.9 & 1775.4 & 13499.3 & 289.6 \\
\hline 10 Jan 02 & 2.22 & 65.00 & 2271.7 & 50.9 & 1892.8 & 14478.4 & 277.4 \\
\hline
\end{tabular}

period at this location. Tidal conditions during the study period resulted in the emersion of lower mid-littoral algae during various hours per day; thus, algae were effectively exposed to these high solar irradiances.

Chlorophyll a fluorescence measurements. In vivo chlorophyll a (chl a) fluorescence of PSII was measured with 2 computer-aided portable pulse modulation fluorometers (PAM 2000 and Diving PAM, Walz). Ten individual samples were taken from each treatment and/or species, incubated for $20 \mathrm{~min}$ in the dark and measured for optimal quantum yield of fluorescence $\left(F_{\mathrm{v}} / F_{\mathrm{m}}\right)$, which is an indicator of quantum efficiency (Schreiber et al. 1994). In the case of Rhodophyta, a modified PAM protocol described by Hanelt et al. (1997b) was used; as in red algae, the onset of maximal fluorescence after a saturating light pulse occurs very quickly, which is associated with excitation of PSI and delay of the $F_{\mathrm{m}}$ decline. The effective quantum yield $\left(\Phi_{\text {PSII }}\right)$, also known as the Genty parameter, was measured in samples not subject to a pre-incubation in the dark (Genty et al. 1989).

For estimation of electron transport rate (ETR), thallus pieces $(n=3)$ were put in a stainless steel chamber and irradiated with increasing intensities of PAR (up to $1500 \mu \mathrm{mol}$ photon $\mathrm{m}^{-2} \mathrm{~s}^{-1}$ ) provided by a halogen lamp of the PAM device (Schreiber et al. 1994). ETR was then estimated by relating $\Phi_{\mathrm{PSII}}$ and the intensity of the actinic irradiance (red-light diode) provided by the PAM instrument:

$$
\mathrm{ETR}=\Phi_{\mathrm{PSII}} \times E_{\mathrm{PAR}} \times A \times 0.5
$$

where $E$ is the incident irradiance of $\mathrm{PAR}, A$ the thallus absorptance, and a factor of 0.5 , which comes from the assumption that 4 of the 8 electrons required to assimilate $1 \mathrm{CO}_{2}$ molecule are supplied by PSII. The absorptance was measured according to the technique described by Mercado et al. (1996), using natural sunlight (average of 10 measurements) as follows:

$$
A=1-T-R
$$

where $T$ is the transmittance (light transmitted throughout the sample) and $R$ is the reflectance (reflected fraction).

To estimate ETR parameters, maximum ETR and the initial slope, defined as the electron transport efficiency at low irradiance, a modified non-linear function from Jassby \& Platt (1976) was fitted to each data set:

$$
\mathrm{ETR}=\mathrm{ETR}_{\max } \times \tanh \left(\alpha_{\mathrm{ETR}} \times E_{\mathrm{PAR}} / \mathrm{ETR}_{\max }\right)
$$

where $\mathrm{ETR}_{\max }$ is the maximal ETR, tanh is the hyperbolic tangent function, $\alpha_{\mathrm{ETR}}$ is the efficiency of the electron transport (initial slope of the ETR vs irradiance curves) and $E$ is the incident irradiance. The saturation irradiance for electron transport $\left(E_{\mathrm{k}}\right)$ was also calculated as the intercept between $\alpha_{\text {ETR }}$ and the ETR max $_{\text {val- }}$ ues. The number of hours for which algae were light saturated $\left(\mathrm{H}_{\mathrm{sat}}\right)$ was calculated from the intersection of $E_{\mathrm{k}}$ and the time in the daily PAR curve according to Gómez et al. (1997).

In situ measurements of $\boldsymbol{\Phi}_{\mathrm{PSII}}$. Daily cycles of pulse amplitude modulated fluorescence were carried out directly in the field using a Diving PAM device (Walz). Measurements were conducted from 08:30 to 20:00 h (local time) on sunny days during December 2001 and January 2002. Algae were measured at 10:00, 11:30, $13: 00,13: 00,14: 30$ and 17:30 h. In the morning and in 
the evening, algae were above the water level (lowest tidal height), whereas during the measurements at noon, algae were slightly covered by the tide. In parallel, the same species were maintained in UV transparent Plexiglas chambers under constant submersion in a tank placed directly on the field site. From these algae, measurements were conducted at 09:30, 11:00, 12:30, 14:00, 15:30 and 19:00 h. The water in the tanks and the chambers was renewed continuously in order to maintain ambient water temperature.

Percentage decrease and recovery of $\Phi_{\text {PSII }}$ were calculated taking into account the values measured in the morning, noon and in the afternoon according to the following formulas:

$\%$ decrease $=\left(\Phi_{\text {PSII(morning) }}-\Phi_{\text {PSII(noon) })}\right) /\left(\Phi_{\text {PSII(morning) })}\right) \times 100$

$\%$ recovery $=\left(\Phi_{\text {PSI (afternoon) }}-\Phi_{\text {PSI(morning) })}\right) /\left(\Phi_{\text {PSII(morning) })}\right) \times 100$

Daily cycles of $F_{\mathrm{v}} / F_{\mathrm{m}}$ and exposure to different natural UV conditions. Algae were collected from the field at different times $(08: 45,10: 30,12: 15,13: 30$, $15: 00,16: 30,18: 00,20: 00 \mathrm{~h}$ ) and incubated for $30 \mathrm{~min}$ in the dark, followed by measurements of $F_{\mathrm{v}} / F_{\mathrm{m}}$. At $08: 45, \quad 13: 30$ and $18: 00 \mathrm{~h}$, samples were taken simultaneously for ETR measurements. Percentage decrease at noon, regarded as photoinhibition, and recovery in the afternoon were calculated similarly using Eqs. (4) \& (5).

To evaluate the contribution of the UV component of the solar radiation on photoinhibition of $F_{\mathrm{v}} / F_{\mathrm{m}}$ some representative species (Porphyra columbina, Mazzaella laminarioides, Macrocystis pyrifera, Enteromorpha intestinalis and Ulva rigida) were examined. Algae were collected, incubated for $30 \mathrm{~min}$ in the dark and measured for $F_{\mathrm{v}} / F_{\mathrm{m}}$. Thereafter, the algae were incubated outdoors under 3 different light climate setups by covering the samples with different cut-off filters: (1) PAR + UV-A + UV-B, by means of an Ultraphan (Digefra $\mathrm{GmbH}$ ), transparent to wavelengths > 295 nm; (2) PAR + UV-A, by use of Folex 320 (Folex $\mathrm{GmbH})$, which cuts off wavelengths $<320 \mathrm{~nm}$; and (3) PAR, by use of Schott-GG $400 \mathrm{~nm}$ (Schott), which cuts off wavelengths $<400 \mathrm{~nm}$.

The spectral characteristics of these filters have been previously described (Wiencke et al. 2000). The incubating system consisted of 3 trays each containing 31 of natural seawater. The trays were put into a large plastic container simulating a water bath, placed close to the shore. The seawater was changed frequently to avoid excessive temperature variations (close to $14^{\circ} \mathrm{C}$ ). Algae were exposed for $2.5 \mathrm{~h}$, which was equivalent to $9.5 \mathrm{~kJ}$ $\mathrm{m}^{-2}$ of UV-B, $170 \mathrm{~kJ} \mathrm{~m}{ }^{-2}$ of UV-A and $3000 \mathrm{~kJ} \mathrm{~m}^{-2}$ of PAR. After measurement, the algae were left to recover for $3 \mathrm{~h}$ under a shading screen to reduce the irradiance.

Pigment analysis. Three samples $(0.1$ to $0.7 \mathrm{~g}$ fresh weight) were taken from selected species, put in plas- tic bags and stored frozen for analysis later. Chlorophylls (chl $a$, chl $b$ and chl $c$ ) and carotenoids were extracted in acetone (90\%) by grinding the algal tissues in a mortar followed by an overnight phase in the dark. The extracts were then centrifuged 2 to 3 times $(3000 \times g, 10 \mathrm{~min}$ each). The absorbance of the supernatant was measured using a spectrophotometer (UNICAM UV-visible, model UV-500), and finally concentrations were estimated from the equations of Jeffrey \& Humphrey (1975). The phycobilins in red algae were analyzed from a water-soluble extract using phosphate buffer ( $\mathrm{pH}$ 6.8). The extracts were then centrifuged for 10 to $15 \mathrm{~min}$ at ca. $5000 \times \mathrm{g}$. The concentrations of phycoerythrin and phycocyanin were finally determined using the equations described by Beer \& Eshel (1985).

Statistical treatment. Data sets were compared using 1 -way ANOVA and in the case of correlated independent variables (e.g. $\alpha_{\text {ETR }}$, ETR $_{\max }$ and $E_{\mathrm{k}}$ from the $P-I$ curves), MANOVA was performed. Data from daily cycles were tested using 2-way ANOVA, with species and time of day being the independent variables. In both types of analysis, post-hoc comparisons of means were performed (Tukey's HSD). Significances were set at $\mathrm{p}<0.005$.

\section{RESULTS}

\section{Pigment contents and optical characteristics}

Contents of pigments were highly variable among species (Table 3). In general, green algae showed the highest chl a concentrations (4.9 to $8.5 \mathrm{mg} \mathrm{g}^{-1}$ dry weight [DW]), while in red and brown algae their concentrations did not exceed $2.5 \mathrm{mg} \mathrm{g}^{-1} \mathrm{DW}$. Accessory pigments such as phycoerythrin (PE) reached the highest concentrations in Callophyllis variegata $\left(8.8 \mathrm{mg} \mathrm{g}^{-1}\right.$ DW) and Gelidium lingulatum (7.2 $\left.\mathrm{mg} \mathrm{g}^{-1} \mathrm{DW}\right)$. Phycocyanin (PC) was high in the shade-type of Porphyra columbina (3.6 $\mathrm{mg} \mathrm{g}^{-1} \mathrm{DW}$ ). In general, differences in the optical characteristics were found as a result of the morpho-functional group: algae attaining leathery or coarsely branched morphs showed the highest absorptances ( $>0.9$ relative units). Differences were also observed between the sun and shade types of Porphyra columbina.

\section{Photosynthetic characteristics}

Photosynthesis versus light curves of the studied algae are shown in Fig. 2. The red alga Gelidium lingulatum, the green algae Enteromorpha intestinalis and Chaetomorpha linum, and the brown alga Macrocystis pyrifera exhibited the highest relative maximal 
Table 3. Pigment composition and thallus absorptance. Values are means \pm SD $(\mathrm{n}=3)$. Chlorophylls (chl $a$, chl $b$, chl $c)$, phycoerythrin (PE) and phycocyanin (PC). Values correspond to algae collected at 09:30 h on December 28 and $29,2001$.

DW $=$ dry weight

\begin{tabular}{|c|c|c|c|c|c|c|}
\hline Species & Chl a & Chl $b$ & $\begin{array}{c}\mathrm{Chl} \mathrm{C} \\
\left.\operatorname{lg~g}^{-1} \mathrm{DW}\right)\end{array}$ & $\mathrm{PE}$ & $\mathrm{PC}$ & $\begin{array}{l}\text { Absorptance } \\
\text { (relative units) }\end{array}$ \\
\hline \multicolumn{7}{|l|}{ Chlorophyta } \\
\hline Ulva rigida & $5.0 \pm 2.3$ & $2.9 \pm 1.5$ & & & & $0.69 \pm 0.03$ (sheet-like) \\
\hline Ulva costata & $4.9 \pm 1.8$ & $2.6 \pm 0.9$ & & & & $0.63 \pm 0.01$ (sheet-like) \\
\hline Chaetomorpha linum & $8.5 \pm 2.7$ & $4.7 \pm 1.5$ & & & & $0.72 \pm 0.06$ (filamentous) \\
\hline Enteromorpha intestinalis & $6.8 \pm 0.9$ & $2.3 \pm 0.3$ & & & & $0.67 \pm 0.02$ (sheet-like) \\
\hline \multicolumn{7}{|l|}{ Rhodophyta } \\
\hline Gelidium lingulatum & $1.5 \pm 0.5$ & & & $7.2 \pm 0.8$ & $0.9 \pm 0.09$ & $0.83 \pm 0.01$ (coarsely branched) \\
\hline Mazzaella laminarioides & $1.5 \pm 0.05$ & & & $0.4 \pm 0.3$ & $0.1 \pm 0.05$ & $0.79 \pm 0.06$ (thick leathery) \\
\hline Callophyllis variegata & $1.0 \pm 0.1$ & & & $8.8 \pm 0.7$ & 0.0 & $0.84 \pm 0.08$ (thin leathery) \\
\hline Porphyra columbina (shade type) & $2.2 \pm 0.9$ & & & $5.3 \pm 1.4$ & $3.6 \pm 0.8$ & $0.77 \pm 0.05$ (sheet-like) \\
\hline Porphyra columbina (sun type) & $1.9 \pm 0.2$ & & & $1.6 \pm 0.8$ & $1.6 \pm 0.7$ & $0.65 \pm 0.03$ (sheet-like) \\
\hline \multicolumn{7}{|l|}{ Phaeophyta } \\
\hline Macrocystis pyrifera & $2.5 \pm 0.6$ & & $0.6 \pm 0.1$ & & & $0.91 \pm 0.04$ (thick leathery) \\
\hline Petalonia fascia & $0.9 \pm 0.2$ & & $0.2 \pm 0.03$ & & & $0.83 \pm 0.05$ (thin leathery) \\
\hline \multicolumn{7}{|l|}{ Phaeophyta } \\
\hline Macrocystis pyrifera & $2.5 \pm 0.6$ & & $0.6 \pm 0.1$ & & & $0.91 \pm 0.04$ (thick leathery) \\
\hline Petalonia fascia & $0.9 \pm 0.2$ & & $0.2 \pm 0.03$ & & & $0.83 \pm 0.05$ (thin leathery) \\
\hline
\end{tabular}

photosynthesis, as estimated from ETR calculations. In general, the results did not reveal differences as a function of the morphology or position at the shore. Most of the red algae had low photosynthesis rates and the highest variations in the curve shape. A detailed summary of the photosynthetic parameters (Table 4) indicated values of photosynthetic efficiency $(\alpha)$ in the range of 0.06 and $0.34\left(\mu \mathrm{mol} \mathrm{e}^{-} \mathrm{m}^{-2} \mathrm{~s}^{-1}\right)$ ( $\mu \mathrm{mol}$ photon $\left.\mathrm{m}^{-2} \mathrm{~s}^{-1}\right)^{-1}$, which were statistically different between species ( $p<0.001$, ANOVA; Tukey's HSD test). ETR $\max$

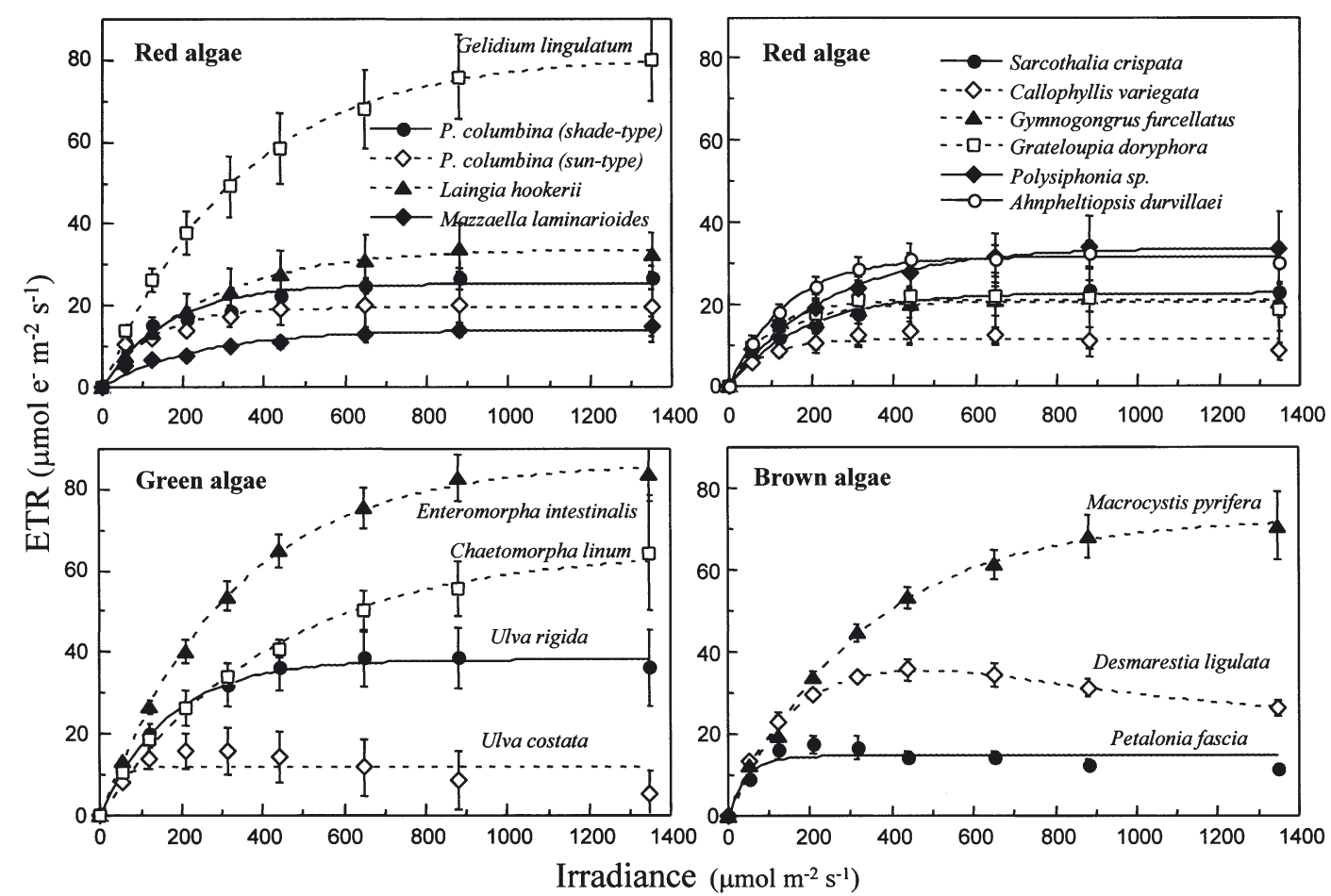

Fig. 2. Photosynthetic versus light curves of the studied species determined using PAM fluorescence (ETR). Light intensities provided by a halogen lamp of the Diving PAM fluorometer. Data are means \pm SD of 3 measurements 
varied largely among species $(\mathrm{p}<0.001)$. Saturation points $\left(E_{\mathrm{k}}\right)$ and $\mathrm{H}_{\mathrm{sat}}$ ranged varied from 50 to $431 \mu \mathrm{mol}$ $\mathrm{e}^{-} \mathrm{m}^{-2} \mathrm{~s}^{-1}$ and from 11.3 to $14 \mathrm{~h} \mathrm{~d}^{-1}$, respectively, and were related to the vertical distribution of the algae, in that algae inhabiting the upper parts of the shore tend to have higher $E_{\mathrm{k}}$ values, and consequently remain saturated during shorter periods $\left(<13 \mathrm{~h} \mathrm{~d}^{-1}\right)$, than algae growing in mid- and infralittoral zones. A resolution using MANOVA confirmed a covariance between the 3 photosynthetic parameters (Wilks' lambda; Rao R index, $\mathrm{p}<0.0001$, Table 4).

Values of $F_{\mathrm{v}} / F_{\mathrm{m}}$ decreased (photoinhibition) during the noon hours coinciding with the onset of solar radiation (Fig. 3). Percentage photoinhibition ranged between 17 and $46 \%$ and varied among species ( $\mathrm{p}$ 0.05 ; Fig. 3B,C, Table 5). In general, algae recovered in the afternoon to values close to or higher than values recorded in the morning ( $p<0.05$, Tukey's HSD test), indicating that a decline in photosynthesis under current solar radiation is a transient phenomenon as a result of dynamic photoinhibition. Only in the sun type of Porphyra columbina, no recovery of $F_{\mathrm{v}} / F_{\mathrm{m}}$ was measured.

In situ measurements of $\Phi_{\mathrm{PSII}}$ (Fig. 4) revealed interspecific variability on a daily basis $(\mathrm{p}<0.05$, ANOVA, Tukey's HSD test). For example, in red algae such as Porphyra columbina (sun type) or the green alga Chaetomorpha linum, decreases in $\Phi_{\text {PSII }}$ were low, whereas in Ulva rigida or Enteromorpha intestinalis, decreases at noon were close to $50 \%$. Likewise, recovery was highly variable ranging between 0 and $130 \%$ ( $p<0.05$; Tukey's HSD test, Table 5). When algae were incubated under similar conditions in emersion into Plexiglas chambers (Fig. 5), decrease and recovery in $\Phi_{\text {PSII }}$ showed lower variation among species (42 to 67 and 85 to $115 \%$, respectively, Table 5). Overall, species and time of day significantly affected the variations in chl a fluorescence (2-way ANOVA, p < 0.001); however, these differences were not related to morphology or vertical distribution.

Table 4. Photosynthetic characteristics determined from electron transport (ETR) measurements and summary of 1-way ANOVA/MANOVA. Units: Quantum efficiency $\left(\alpha\right.$, defined as the initial slope of the $P$ - $I$ curve; $\left[\mu \mathrm{mol} \mathrm{e}^{-} \mathrm{m}^{-2} \mathrm{~s}^{-1}\right]\left[\mu \mathrm{mol} \mathrm{m}^{-2} \mathrm{~s}^{-1}\right]^{-1}$ ),

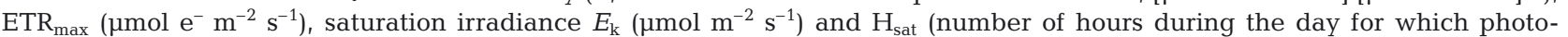
synthesis is saturated; $h$ ). Data are means $\pm S D, n=4$. Similar letters denote non-significant differences among means at $p<0.05$ (Tukey's HSD)

\begin{tabular}{|c|c|c|c|c|}
\hline Species & Quantum efficiency $(\alpha)$ & $\mathrm{ETR}_{\max }$ & $E_{\mathrm{k}}$ & $\mathrm{H}_{\text {sat }}$ \\
\hline \multicolumn{5}{|l|}{ Chlorophyta } \\
\hline Ulva rigida & $0.22 \pm 0.02 \mathrm{a}$ & $38.2 \pm 7.1 \mathrm{a}$ & $167.5 \pm 27.1 \mathrm{a}$ & 13.37 \\
\hline Ulva costata & $0.26 \pm 0.06 \mathrm{a}$ & $16.5 \pm 5.0 \mathrm{~b}$ & $78.5 \pm 6.4 \mathrm{~b}$ & 14.00 \\
\hline Chaetomorpha linum & $0.15 \pm 0.009 \mathrm{~b}$ & $66.2 \pm 17.1 \mathrm{C}$ & $431.4 \pm 140.5 \mathrm{C}$ & 11.31 \\
\hline Enteromorpha intestinalis & $0.26 \pm 0.01 \mathrm{a}$ & $86.6 \pm 6.5 \mathrm{c}$ & $324.4 \pm 9.7 \mathrm{c}$ & 12.29 \\
\hline \multicolumn{5}{|l|}{ Rhodophyta } \\
\hline Laingia hookerii & $0.13 \pm 0.03 \mathrm{~b}$ & $33.8 \pm 5.6 \mathrm{a}$ & $256.1 \pm 25.6 \mathrm{C}$ & 12.50 \\
\hline Gelidium lingulatum & $0.34 \pm 0.03 \mathrm{c}$ & $80.9 \pm 10.4 \mathrm{C}$ & $335.6 \pm 21.2 \mathrm{c}$ & 12.26 \\
\hline Mazzaella laminarioides & $0.06 \pm 0.01 \mathrm{~d}$ & $14.1 \pm 2.3 \mathrm{~b}$ & $237.2 \pm 73.8 \mathrm{a}$ & 12.54 \\
\hline Ahnfeltiopsis durvillaei & $0.22 \pm 0.02 \mathrm{a}$ & $31.3 \pm 3.7 \mathrm{a}$ & $138.6 \pm 8.7 \mathrm{a}$ & 13.23 \\
\hline Polysiphonia sp. & $0.14 \pm 0.005 \mathrm{~b}$ & $33.8 \pm 8.7 \mathrm{a}$ & $237.4 \pm 69.6 \mathrm{a}$ & 12.53 \\
\hline Gracilaria chilensis & $0.15 \pm 0.004 \mathrm{a}$ & $28.2 \pm 4.6 \mathrm{a}$ & $182.8 \pm 34.1 \mathrm{c}$ & 13.15 \\
\hline Grateloupia doryphora & $0.21 \pm 0.04 \mathrm{~b}$ & $21.2 \pm 2.7 \mathrm{~b}$ & $104.0 \pm 35.5 \mathrm{a}$ & 13.47 \\
\hline Gymnogongrus furcellatus & $0.16 \pm 0.04 \mathrm{~b}$ & $20.7 \pm 11.3 b$ & $117.7 \pm 47.1 \mathrm{a}$ & 13.31 \\
\hline Callophyllis variegata & $0.14 \pm 0.02 \mathrm{~b}$ & $11.2 \pm 2.3 \mathrm{a}$ & $81.9 \pm 20.1 \mathrm{~b}$ & 13.57 \\
\hline Sarcothalia crispata & $0.13 \pm 0.002 \mathrm{~b}$ & $24.8 \pm 5.6 \mathrm{a}$ & $181.7 \pm 40.2 \mathrm{a}$ & 13.15 \\
\hline Porphyra columbina (shade type) & $0.14 \pm 0.01 \mathrm{a}$ & $25.6 \pm 2.6 \mathrm{a}$ & $179.9 \pm 25.1 \mathrm{a}$ & 13.15 \\
\hline Porphyra columbina (sun type) & $0.20 \pm 0.09 \mathrm{a}$ & $20.5 \pm 7.6 \mathrm{a}$ & $136.5 \pm 116.1 \mathrm{a}$ & $13: 27$ \\
\hline \multicolumn{5}{|l|}{ Phaeophyta } \\
\hline Macrocystis pyrifera & $0.22 \pm 0.01 \mathrm{a}$ & $72.3 \pm 8.1 \mathrm{c}$ & $327.4 \pm 45.1 \mathrm{c}$ & 12.28 \\
\hline Petalonia fascia & $0.34 \pm 0.04 \mathrm{C}$ & $17.0 \pm 2.0 \mathrm{~b}$ & $50.9 \pm 12.4 \mathrm{~b}$ & 14.00 \\
\hline Desmarestia ligulata & $0.25 \pm 0.02 \mathrm{a}$ & $36.1 \pm 2.4 \mathrm{a}$ & $144.8 \pm 7.1 \mathrm{a}$ & 13.23 \\
\hline \multicolumn{5}{|l|}{ ANOVA } \\
\hline Mean SS & 0.02 & 1869.9 & 31534.7 & \\
\hline Mean SS Error & 0.005 & 51.6 & 1937.9 & \\
\hline$F_{(1,2) 12,41}$ & 3.9 & 36.1 & 16.2 & \\
\hline p-level & $\mathrm{p}<0.0001$ & $\mathrm{p}<0.0001$ & $\mathrm{p}<0.0001$ & \\
\hline \multicolumn{5}{|l|}{ MANOVA } \\
\hline \multicolumn{5}{|l|}{ Wilks' lambda $=0.01$} \\
\hline Rao $\mathrm{R}_{(51,116)}=8.4, \mathrm{p}<0.0001$ & & & & \\
\hline
\end{tabular}




\section{Photoinhibition and recovery after short-term exposure to different light treatments}

The 5 representative species of red, green and brown algae showed differences in $F_{\mathrm{v}} / F_{\mathrm{m}}$ related to species and treatments $(\mathrm{p}<0.001$, Table 6$)$. After the $2.5 \mathrm{~h}$ exposure to full solar radiation (PAR + UV-A +
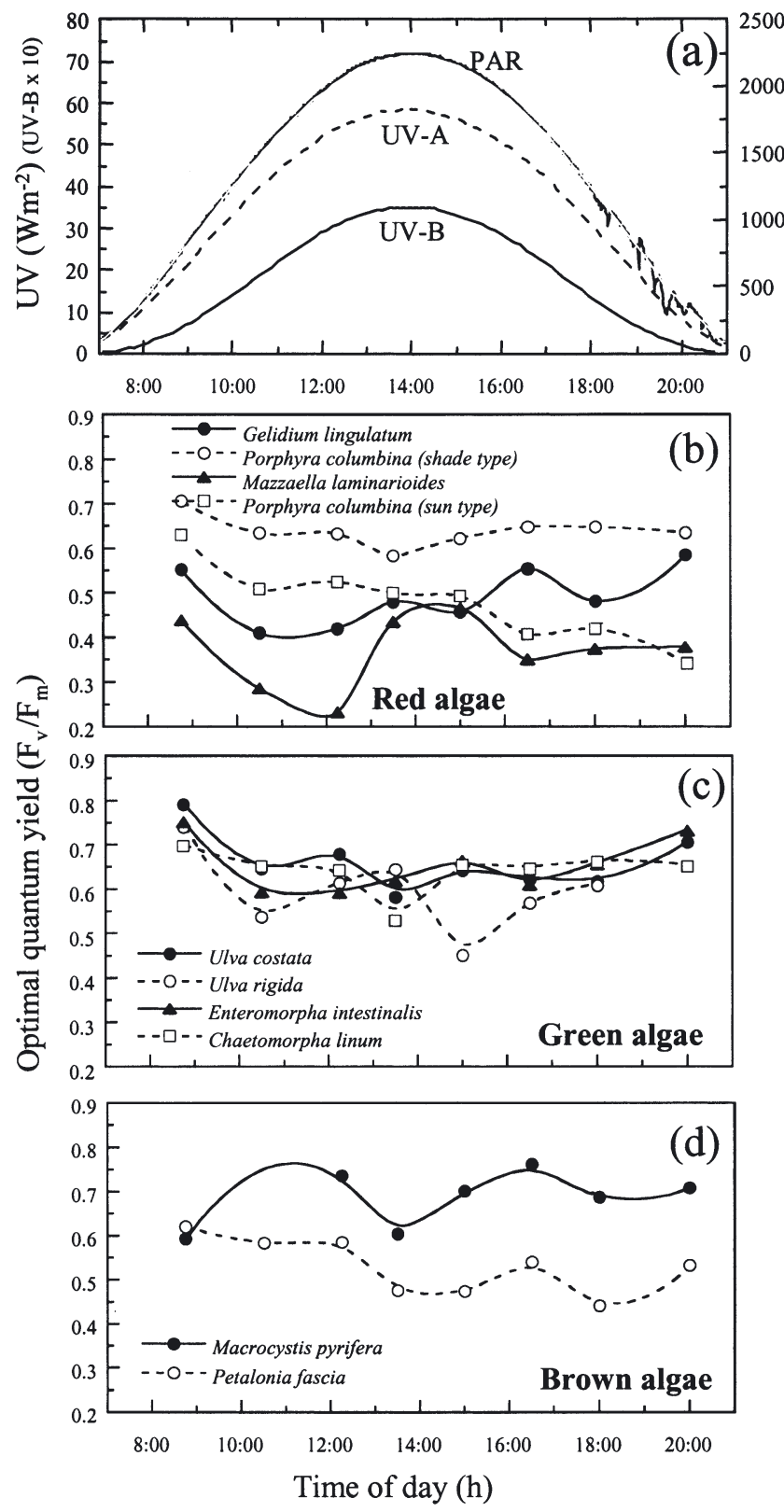

Fig. 3. Course of maximal quantum yield of chlorophyll a (chl a) fluorescence measured in algae collected at different times on December 29, 2001 at Niebla, Valdivia. (a) Irradiances of UV (UV-B multiplied by 10) and PAR, (b) photosynthesis in red, (c) green, (d) brown algae. Data are means, $\mathrm{n}=7$ to 10 . SDs do not exceed $20 \%$ and were omitted for clarity
UV-B), chl a fluorescence decreased by $25 \%$ in Macrocystis pyrifera, whereas in Mazzaella laminariodes and Enteromorpha intestinalis, photoinhibition of photosynthesis was close to 13 and 8\%, respectively. In Ulva rigida and Porphyra columbina (shade type), photoinhibition did not exceed $5 \%$. In incubations under PAR + UV-A, photoinhibition followed a similar pattern. Only in Porphyra was no photoinhibition seen. In general, with the exception of a $13 \%$ decrease in Macro-
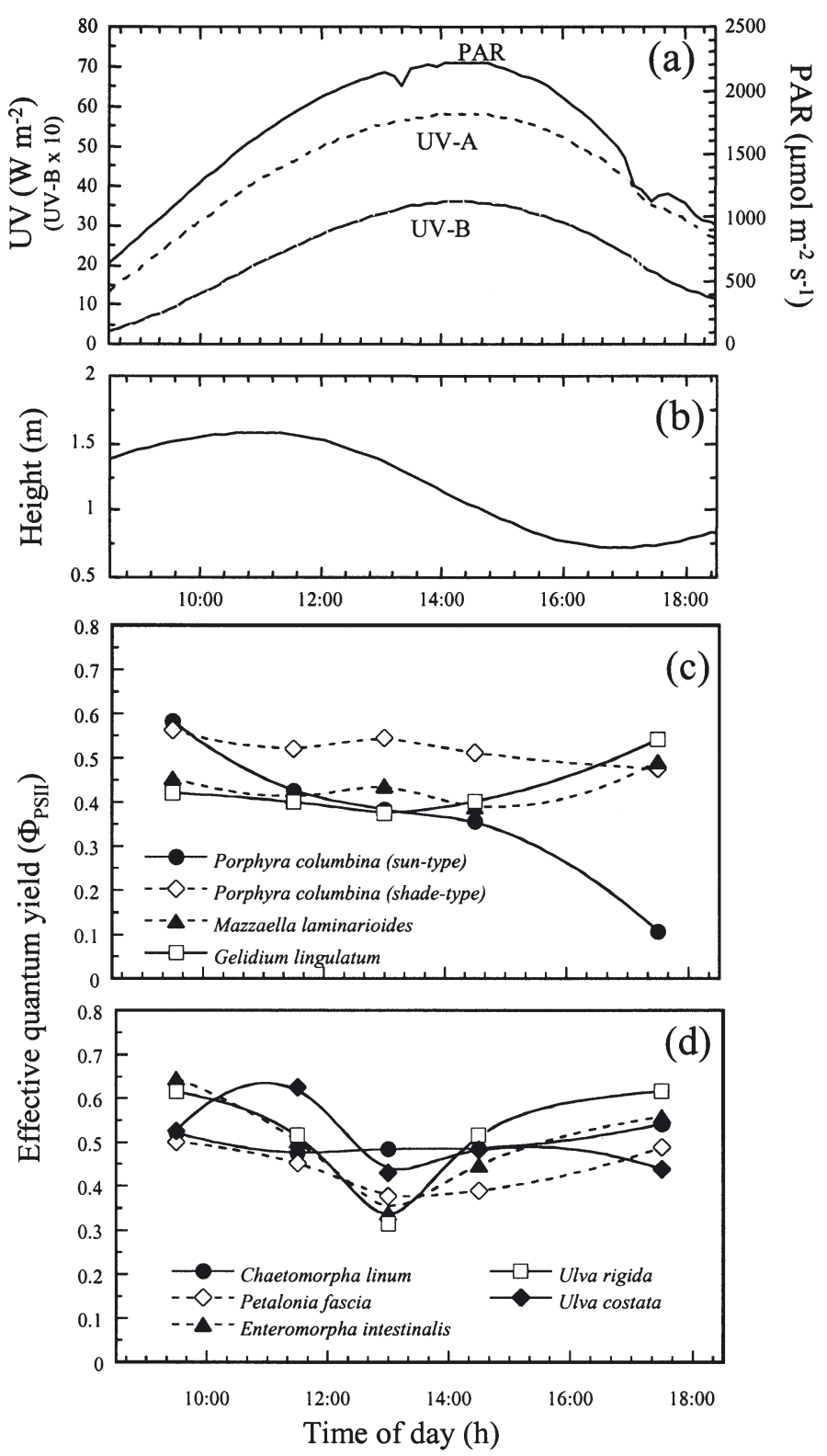

Fig. 4. Course of effective quantum yield $\left(\Phi_{\mathrm{PSII}}\right)$ measured in situ on January 3, 2002 at Niebla, Valdivia. (a) Irradiances of UV radiation (UV-B multiplied by 10) and PAR, (b) tidal cycle, $(\mathrm{c}, \mathrm{d})$ effective quantum yield of red, green and brown algae. Data are means, $\mathrm{n}=7$ to 10 . SDs do not exceed $20 \%$ and were omitted for clarity 

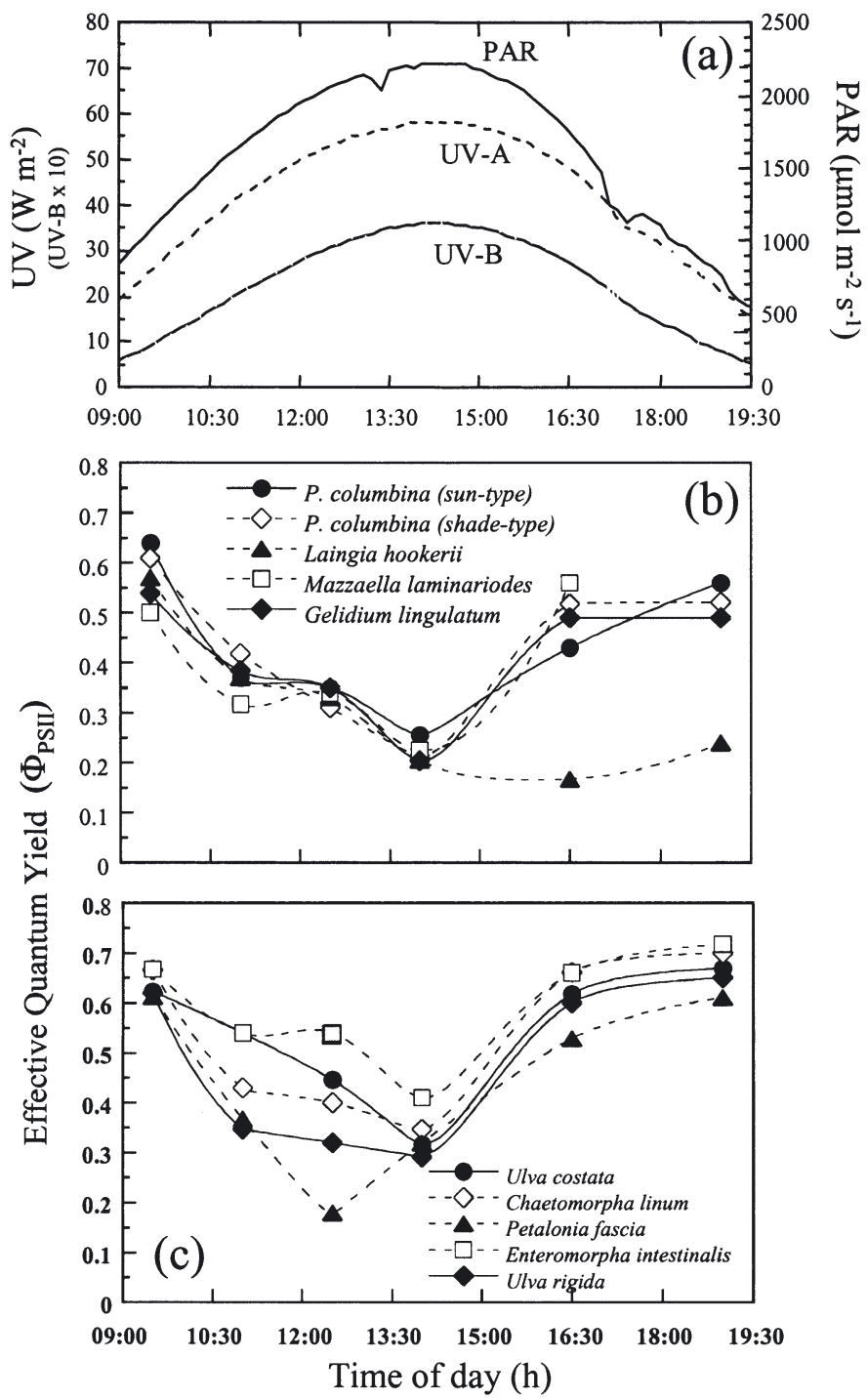

Fig. 5. Course of effective quantum yield of chlorophyll a (chl a) fluorescence $\left(\Phi_{\mathrm{PSII}}\right)$ measured at different times during a day in algae incubated in UV transparent Plexiglas chambers under natural solar radiation. (a) Irradiances of UV radiation (UV-B multiplied by 10) and PAR, (b) photosynthesis in red, (c) brown and green algae. Data are means, $\mathrm{n}=7$ to 10 . SDs do not exceed $20 \%$ and were omitted for clarity

cystis pyrifera, PAR alone did not stimulate significant decreases in $F_{\mathrm{v}} / F_{\mathrm{m}}(\mathrm{p}>0.05)$. Recoveries ranging from 80.5 to $112.5 \%$ were found in all the studied species.

\section{DISCUSSION}

The results from this study indicate that intertidal seaweeds are currently exposed to photoinhibitory irradiances during summer. This is a novel finding for algae from Chile and is consistent with previous data from laboratory and field studies on other macroalgal populations in the northern and southern Hemisphere (Hanelt et al. 1993, 1994a, 1997b, Franklin et al. 1996, Jiménez et al. 1998). During sunny days in austral summer, recorded values of PAR and UV were higher than previously measured in equivalent latitudes in the northern hemisphere, mainly due to solar angle and absence of polluting aerosols. Although variations in ozone level occurred, stratospheric ozone-conditioned enhancements of solar UV-B radiation may be regarded as a phenomenon restricted to short-term episodes, generally detectable in spring months (Lovengreen et al. 2000). Algae inhabiting the intertidal platform in Niebla, Valdivia, were well adapted to these environmental light conditions, which could be demonstrated by a clear expression of dynamic photoinhibition at noon and total recovery in the afternoon. In all the studied species, photosynthesis both measured as $\Phi_{\text {PSII }}$ and $F_{\mathrm{v}} / F_{\mathrm{m}}$ decreased at noon and recovered (with exception of 1 species) in the afternoon. During the onset of solar radiation, the high irradiances of PAR and UV became stressful for algae, which however showed the capability for dynamic photoinhibition, i.e. a transient downregulation of the PSII, photosynthesis then recovering to levels close to or higher than the morning values.

\section{Photoinhibition versus morphology}

Thallus morphology, thickness and pigmentation strongly determine light harvesting capacity of macroalgae. The various cell layers, characterized by different optical properties, cause self-shading and light scattering, which results in differential light absorption (Ramus 1978, Enríquez et al. 1994, Raven \& Kübler 2002). In our study, the sheet-like morphs were characterized by the lowest absorptances (0.6 to 0.8 relative units). Pigmentation also varied between species and morphs, and was related to the taxonomic groups. Accessory pigments such as phycobilins in red algae also accounted for increased absorptance as compared to other groups. Interestingly, 2 ecotypes of Porphyra columbina, the shade and sun types, attained similar morphology, but their absorptances were different due to higher concentrations of phycobilins (Table 3). Pigment concentrations in macroalgae can be highly variable depending on different light related factors that can determine their daily changes, mainly due to photoacclimation (Algarra \& Niell 1987, Henley \& Ramus 1989, Figueroa et al. 1997, Sagert \& Schubert 2000). We measured pigment concentrations over the day; however, the variations were erratic and no defined patterns were detected (data not shown). Thus, the survey of pigment contents merely serves to 
indicate the ranges occurring in these species, which hitherto have not previously been reported.

In our study, we were not able to conclude any morphology-dependent effect when the different photosynthetic parameters were compared among species (Table 4). These results are in accordance with the data reported by Johansson \& Snoeijs (2002) for algae from the Baltic Sea and Swedish fjords. These authors found only some morphology-dependent patterns in $\mathrm{O}_{2}$-based $P_{\max }$ and $\alpha$, whereas data from light requirements for photosynthesis $\left(E_{\mathrm{c}}\right.$ and $\left.E_{\mathrm{k}}\right)$ were not correlated to morpho-functional groups. Photosynthesis data, including photoinhibition and recovery patterns, reported in our study, were estimated from the chl a fluorescence measurements, and so are strongly dependent on photochemical processes. Even in polar algae, regarded as shade adapted, their low requirements for photosynthesis $\left(<70 \mu \mathrm{mol}\right.$ photon $\left.\mathrm{m}^{-2} \mathrm{~s}^{-1}\right)$ are not affected by morphology (Weykam et al. 1996, Gómez et al. 1997). Such findings suggest that macroalgae, in virtue of their photobiological performance, are highly variable and possess, irrespective of their thallus architecture, a potential to adapt to changing light environments characterizing shallow waters.

Similarly, in the case of responses to UV, the importance of morphology becomes minor when photoinhibition and recovery rates are examined. Although decrease and subsequent recovery in $F_{\mathrm{v}} / F_{\mathrm{m}}$ were
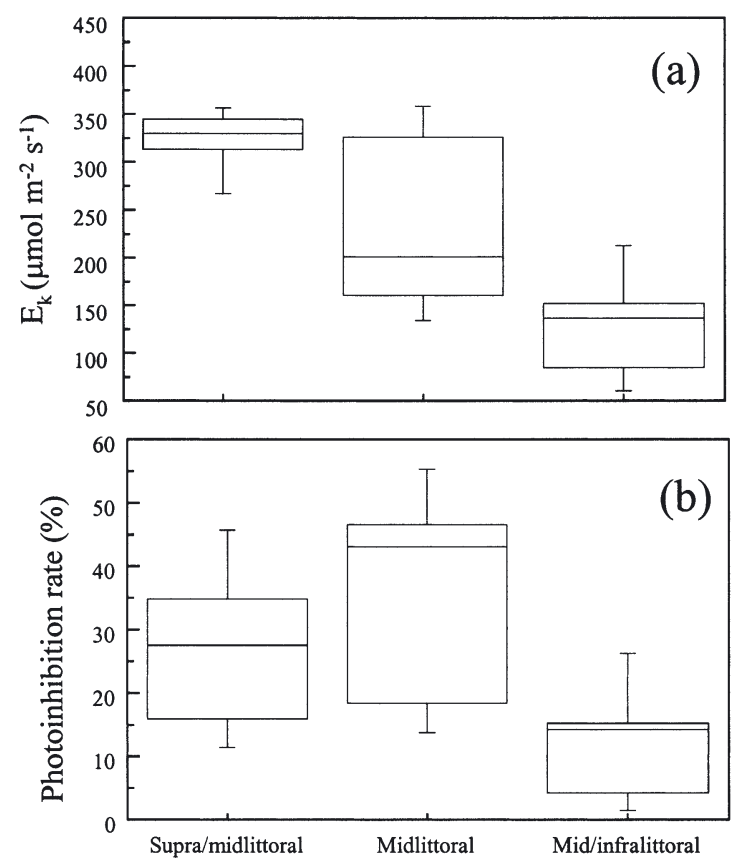

Fig. 6. Box-plot indicating (a) light requirements for photosynthesis $\left(E_{\mathrm{k}}\right)$ and (b) photoinhibition of photosynthesis in algae from different sites on the intertidal shore. Plots represent medians and upper/lower quartiles of each data set statistically different among species, they were not related to morpho-functional groups. For example, Macrocystis pyrifera, a thick leathery species, had a comparable photosynthetic response after $2.5 \mathrm{~h}$ exposure to different UV conditions to the green alga Enteromorpha intestinalis, a species with a sheet-like thallus structure (Fig. 5). These data indicate that UV tolerance involves metabolic adjustments, e.g. shade and sun characteristics, rather than morphological traits. The reported morphology-dependent susceptibility of macroalgae to UV radiation has generally been studied in different life history stages (Dring 1996a, Hanelt et al. 1997a, Huovinen et al. 2000). Due to their thin thallus structure early stages normally suffer enhanced detrimental effects on, e.g. photosynthesis, as compared to thicker, adult forms. In general, screening studies examining physiological responses (photosynthesis, pigment content, growth, etc.) of various macroalgal groups to UV radiation do not conclusively show morphology-related responses (Larkum \& Wood 1993, Yakovleva et al. 1998, Aguilera et al. 1999). Instead, other factors such as position on the shore strongly determine physiological performance of algae as has been reported for, e.g. sun and shade ecotypes of the red algal genera Porphyra (Figueroa et al. 2003) and Gelidium (Gómez \& Figueroa 1998). In these species, shade types suffered from chronic photoinhibition, whereas their sun-adapted counterparts showed dynamic photoinhibition. Apparently, sunadapted algae are better suited to coping not only with enhanced solar radiation, but also with simultaneously high temperature, salinity and desiccation (Davison \& Pearson 1996).

\section{Photoinhibition versus intertidal zonation}

In situ determination of $\Phi_{\mathrm{PSII}}$ indicated that higher decreases at noon (>30\%) occurred in species in upper littoral locations as compared to species growing at lower zones $(<20 \%$, Fig. 6 , Table 5$)$. In the case of the sun type of Porphyra columbina, no recovery was measured in the course of the studied period. Probably, desiccation at the supralittoral delayed recovery, which occurs later at sunset or overnight. Interestingly, the tidal course affected the patterns of photoinhibition and recovery, which was also confirmed in an experiment where algae were incubated during a day under immersion in Plexiglas containers (Fig. 5). Here, the rates of photoinhibition were quite similar among species and higher than in in situ measurements, and with the exception of Laingia hookerii, an infralittoral species, recovery reached the values measured initially in the morning. Higher photoinhibition rates during immersed conditions compared to conditions in which 
algae were exposed for a long time to the air can be explained by the daily tidal course: during the period of decrease in $\Phi_{\text {PSII }}(08: 00$ to $13: 30 \mathrm{~h})$, the tide was still high $(1 \mathrm{~m})$, which could ameliorate photoinhibition due to increasing absorption and scattering of light, while the low tide (16:00 to 19:00 h) coincided with the beginning of the recovery and lower incident irradiances. In contrast, algae kept in the Plexiglas chambers were submerged just under the water surface, and thus were exposed to comparatively higher irradiances than their counterparts measured in situ. Tidal dependence of photoinhibition of photosynthesis has been described in marine macrophytes from South China (Hanelt et al. 1994b), emphasizing the effect of changing tidal levels on the daily course of photosynthesis and on the magnitude of the light stress in intertidal algae.

Although all of the studied species can be regarded as purely intertidal, in situ decreases in $\Phi_{\text {PSII }}$ resemble those described for algal populations from other latitudes based on depth distribution (Franklin et al. 1996, Hanelt 1998). However, in terms of photoinhibition capabilities, such as the decrease in $F_{\mathrm{v}} / F_{\mathrm{m}}$ the intertidal algae examined in the present study show a broad range of responses. Taking into account the light requirements for photosynthesis, algae from upper littoral zones have higher $E_{\mathrm{k}}$ values than algae growing on mid- or infralittoral fringe (Fig. 6a). However, only algae collected from mid-infralittoral zones exhibit obviously lower photoinhibition rates (Fig. 6b). As was mentioned above, $E_{\mathrm{k}}$ values were not correlated to morpho-functional attributes, and thus algae set their optimal photosynthetic performance in response to the light environment (Franklin et al. 1996). Hence, to cope with the high summer solar radiation at the intertidal level, algae have to display efficient photoinhibitory adjustments, irrespective of their photosynthetic machinery (e.g. thylakoid membrane and light-harvesting apparatus) or morphology (e.g. thin vs. thick morphs). This was clearly confirmed in the short-term exposures to different UV climates (Table 6). Algae from different locations at the shore and attaining different thallus form were not largely affected by UV radiation. In general, photoinhibition did not exceed $20 \%$ at UV-B doses close to $10 \mathrm{~kJ} \mathrm{~m}^{-2}$ $\mathrm{s}^{-1} \mathrm{~d}^{-1}$, indicating a high potential to tolerate enhanced solar radiation resembling data reported for some warm temperate species normally exposed to very high solar radiation (Gómez et al. 1998, PérezRodríguez et al. 1998, Figueroa \& Gómez 2001). The high PAR doses to which algae were exposed during the experiments (close to $3000 \mathrm{~kJ} \mathrm{~m}^{-2}$ ) could also justify their low susceptibility to photoinhibition under UV radiation. The importance of PAR has been recognized in the reactions involved in photoinhibition of photosynthesis, which photochemically can be defined as the light-dependent decline in photosynthetic efficiency (energy dissipation within the light-harvesting complex II [LHCII] antenna complex of PSII) when PAR photons absorbed exceed the requirements for photosynthesis (Osmond 1994).

Finally, another explanation for the tolerance of these species to solar UV radiation may be high concentrations of photoprotective pigments. Although we do not show data on UV-absorbing mycosporine-like amino acids (MAAs), parallel to the present study, a survey of MAAs was carried and these results are presented in a separate paper (Huovinen et al. 2004). Those results indicated values as high as $10 \mathrm{mg} \mathrm{g}^{-1}$ DW, exceeding maximal MAA contents measured in species from other geographical locations $\left(<7.8 \mathrm{mg} \mathrm{g}^{-1}\right.$ DW; Karsten et al. 1998, Hoyer et al. 2001).

Acknowledgements. This study was supported by grants from the Universidad Austral de Chile (DID S-2002-25 to I.G. and DID S-2001-04 to C.L.), the Universidad de Málaga (AGL2001-1888-CO3-02) to F.L.F, and the Academy of Finland (No. 102832) to P.H. The authors thank J. Navarro (Instituto de Biología Marina, Universidad de Austral de Chile) for providing facilities for pigment analysis.

\section{LITERATURE CITED}

Aguilera J, Karsten U, Lippert H, Vögele B, Philipp E, Hanelt D, Wiencke C (1999) Effects of solar radiation on growth, photosynthesis and respiration of marine macroalgae from the Arctic. Mar Ecol Prog Ser 191:109-119

Algarra P, Niell FX (1987) Structural adaptations to light reception in two morphotypes of Corallina elongata Ellis \& Soland. PSZN I: Mar Ecol 8:253-261

Altamirano M, Flores-Moya A, Conde F, Figueroa FL (2000) Growth seasonality, photosynthetic pigments, and carbon and nitrogen content in relation to environmental factors: a field study of Ulva olivascens. Phycologia 39:50-58

Beer S, Eshel A (1985) Determining phycoerythrin and phycocyanin concentrations in aqueous crude extracts of red algae. Aust J Mar Freshw Res 36:785-792

Bischof K, Hanelt D, Tüg H, Karsten U, Brouwer PEM, Wiencke C (1998) Acclimation of brown algal photosynthesis to ultraviolet radiation in Arctic coastal waters (Spitsbergen, Norway). Polar Biol 20:388-395

Bischof K, Hanelt D, Wiencke C (2000) Effects of ultraviolet radiation on photosynthesis and related enzyme reactions of marine macroalgae. Planta 211:555-562

Bothwell ML, Sherbot DMJ, Pollock CM (1994) Ecosystem response to solar ultraviolet $\mathrm{B}$ radiation: influence of trophic-level interaction. Science 265:97-100

Davison IR, Pearson GA (1996) Stress tolerance in intertidal seaweeds. J Phycol 32:197-211

Dring MJ, Makarov V, Schoschina E, Lorenz M, Lüning K (1996a) Influence of ultraviolet radiation on chlorophyll fluorescence and growth in different life history stages of three species of Laminaria (Phaeophyta). Mar Biol 126: 183-191

Dring MJ, Wagner A, Boeskov J, Lüning K (1996b) Sensitivity of intertidal and subtidal red algae to UVA and UVB radiation, as monitored by chlorophyll fluorescence measurements: influence of collection depth, and season, and 
length of irradiance. Eur J Phycol 31:293-302

Enríquez S, Agustí S, Duarte C (1994) Light absorption by marine macrophytes. Oecologia 98:121-129

Figueroa FL, Gómez I (2001) Photosynthetic acclimation to solar UV radiation of marine red algae from the warmtemperate coast of southern Spain. A review. J Appl Phycol 13:235-248

Figueroa FL, Salles S, Aguilera J, Jiménez C, Mercado J, Viñegla B, Flores-Moya A, Altamirano M (1997) Effects of solar radiation on photoinhibition and pigmentation in the red alga Porphyra leucosticta. Mar Ecol Prog Ser 151: $81-90$

Figueroa FL, Escassi L, Pérez-Rodríguez E, Korbee N, Giles AD, Johnsen G (2003) Effects of short-term irradiation on photoinhibition and accumulation of mycosporine-like amino acids in sun and shade species of the red algal genus Porphyra. J Photochem Photobiol B Biol 21-30

Franklin LA, Seaton GGR, Lovelock CE, Larkum AWD (1996) Photoinhibition of photosynthesis on a coral reef. Plant Cell Environ 19:825-836

Genty B, Briantais JM, Baker NR (1989) The relation between the quantum yield of photosynthetic electron transport and quenching of chlorophyll fluorescence. Biochim Biophys Acta 990:87-92

Gómez I, Figueroa FL (1998) Effects of solar UV stress on chlorophyll fluorescence kinetics of intertidal macroalgae from southern Spain: a case study in Gelidium species. J Appl Phycol 10:285-294

Gómez I, Westermeier R (1991) Frond regrowth from basal disc in Iridaea laminarioides (Rhodophyta, Gigartinales) at Mehuín, southern Chile. Mar Ecol Prog Ser 73:83-91

Gómez I, Weykam G, Klöser H, Wiencke C (1997) Photosynthetic light requirements, metabolic carbon balance and zonation of sublittoral macroalgae from King George Island (Antarctica). Mar Ecol Prog Ser 148:281-293

Gómez I, Pérez-Rodríguez E, Viñegla B, Figueroa FL, Karsten U (1998) Effects of solar radiation on photosynthesis, UVabsorbing compounds and enzyme activities of the green alga Dasycladus vermicularis from southern Spain. J Photochem Photobiol B Biol 47:46-57

Grobe CW, Murphy TM (1998) Solar ultraviolet-B radiation effects on growth and pigment composition of the intertidal alga Ulva expansa (Setch.) S \& G. (Chlorophyta). J Exp Mar Biol Ecol 225:39-51

Hanelt D (1998) The capability for dynamic photoinhibition in Arctic macroalgae is related to their depth distribution. Mar Biol 131:361-369

Hanelt D, Huppertz K, Nultsch W (1993) Daily course of photosynthesis and photoinhibition in marine macroalgae investigated in the laboratory and in the field. Mar Ecol Prog Ser 97:31-71

Hanelt D, Jaramillo J, Nultsch W, Senger S, Westermeier R (1994a) Photoinhibition as a regulative mechanism of photosynthesis in marine algae of Antarctica. Ser Cient Inst Antart Chile 44:67-77

Hanelt D, Li J, Nultsch W (1994b) Tidal dependence of photoinhibition of photosynthesis in marine macrophytes of south China Sea. Bot Acta 107:66-72

Hanelt D, Wiencke C, Karsten U, Nultsch W (1997a) Photoinhibition and recovery after high light stress in different developmental and life-history stages of Laminaria saccharina (Phaeophyta). J Phycol 22:387-395

Hanelt D, Wiencke C, Nultsch W (1997b) Influence of UV radiation on the photosynthesis of Arctic macroalgae in the field. J Photochem Photobiol B Biol 40-47

Henley WJ, Ramus J (1989) Optimization of pigment content and the limits of photo-acclimation for Ulva rotundata
(Chlorophyta). Mar Biol 103:267-274

Hoyer K, Karsten U, Sawall T, Wiencke C (2001) Photoprotective substances in Antarctic macroalgae and their variation with respect to depth distribution, different tissues and developmental stages. Mar Ecol Prog Ser 211: $117-129$

Huovinen P, Oikari AOJ, Soimasuo MR, Cherr GN (2000) Impact of UV radiation on the early development of the giant kelp (Macrocystis pyrifera) gametophytes. Photochem Photobiol 72:308-313

Huovinen P, Gómez I, Figueroa FL, Ulloa U, Morales V, Lovengreen C (2004) Absorbing mycosporine-like amino acids in red macroalgae from Chile. Bot Mar 47:21-29

Jassby AD, Platt T (1976) Mathematical formulation of the relationship between photosynthesis and light for phytoplankton. Limnol Oceanogr 21:540-547

Jeffrey SW, Humphrey GF (1975) New spectrophotometric equation for determining chlorophyll $a, b, c 1$ and $c 2$. Biochem Physiol Pflanz 167:194-204

Jiménez C, Figueroa FL, Salles S, Aguilera J and 5 others (1998) Effects of solar radiation on photosynthesis and photoinhibition in red macrophytes from an intertidal system of southern Spain. Bot Mar 41:329-338

Johansson G, Snoeijs P (2002) Macroalgal photosynthetic responses to light in relation to thallus morphology and depth zonation. Mar Ecol Prog Ser 244:63-72

Karsten U, Sawall T, Hanelt D, Bischof K, Figueroa FL, FloresMoya A, Wiencke C (1998) An inventory of UV-absorbing mycosporine-like amino acids in macroalgae from polar to warm-temperate regions. Bot Mar 41:443-453

Larkum AWD, Wood WF (1993) The effect of UV-B on photosynthesis and respiration of phytoplankton, benthic macroalgae and seagrasses. Photosynth Res 36:17-23

Littler MM, Littler DS (1980) The evolution of thallus form and survival strategies in benthic marine macroalgae: field and laboratory tests of a functional form model. Am Nat 116:25-44

Lovengreen C, Fuenzalida H, Villanueva L (2000) Ultraviolet solar radiation at Valdivia, Chile $\left(39.8^{\circ} \mathrm{S}\right)$. Atmos Environ 34:4051-4061

Lüning K (1990) Seaweeds. Their environment, biogeography, and ecophysiology. Wiley-Liss, New York

McKenzie RL, Bodeker GE, Keep DJ, Kotkamp M, Evans J (1996) UV radiation in New Zealand: north-to south differences between two sites, and relationship to other latitudes. Weather Climate 16:17-26

Mercado JM, Jiménez C, Niell FX, Figueroa FL (1996) Comparison of methods for measuring light absorption by algae and their application to the estimation of the package effect. Sci Mar 60:39-45

Osmond CB (1994) What is photoinhibition? Some insights from sun and shade plants. In: Baker NR, Bowyer NR (eds) Photoinhibition of photosynthesis: from the molecular mechanisms to the field. BIOS Scientific Publishing, Oxford, p 1-24

Pakker H, Beekman CAC, Breeman AM (2000a) Efficient photoreactivation of UVBR-induced DNA damage in the sublittoral macroalga Rhodymenia pseudopalmata (Rhodophyta). Eur J Phycol 35:109-114

Pakker H, Martins R, Boelen P, Buma AGJ, Nikaido, Breeman AM (2000b) Effects of temperature on the photoreactivation of ultraviolet-B-induced DNA damage in Palmaria palmata (Rhodophyta). J Phycol 36:334-341

Pang S, Gómez I, Lüning K (2001) The red macroalgae Delesseria sanguinea as a UVB-sensitive model organisms: selective growth reduction by UVB in outdoor experiments and rapid recording of growth rate during and after 
UV pulses. Eur J Phycol 36:207-216

Pérez-Rodríguez E, Gómez I Karsten U, Figueroa FL (1998) Effects of UV radiation on photosynthesis and excretion of UV-absorbing compounds of Dasycladus vermicularis (Dasycladales, Chlorophyta) from southern Spain. Phycologia 37:379-387

Ramus J (1978) Seaweed anatomy and photosynthetic performance: the ecological significance of light guides, heterogeneous absorption and multiple scatter. J Phycol 14: 352-362

Raven JA, Kübler JE (2002) New light on the scaling of metabolic rate with the size of algae. J Phycol 38:11-16

Sagert S, Schubert H (2000) Acclimation of Palmaria palmata (Rhodophyta) to light intensity: comparison between artificial and natural light fields. J Phycol 36:1119-1128

Santelices B (1980) Phytogeographic characterization of the temperate coast of Pacific South America. Phycologia 19:1-2

Schreiber U, Bilger W, Neubauer (1994) Chlorophyll fluorescence as a non intrusive indicator for rapid assessment of in vivo photosynthesis. Ecol Stud 100:49-70

Seckmeyer G, Mayer B, Bernhard G, McKenzie RL and 8 others (1995) Geographical differences in the UV measured by intercompared spectroradiometers. Geophys Res Lett 22:1889-1892

SERNAPESCA (2001) Anuario estadístico de Pesca. Servicio

Editorial responsibility: Otto Kinne (Editor),

Oldendorf/Luhe, Germany
Nacional de Pesca, Chile

van de Poll WH, Eggert A, Buma AGJ, Breeman AM (2001) Effects of UV-B-induced DNA damage and photoinhibition on growth of temperate marine red macrophytes: habitat-related differences in UV-B tolerance. J Phycol 37: $30-37$

Westermeier R, Möller P (1990) Population dynamics of Macrocystis pyrifera (L) C. Ag. in the rocky intertidal of southern Chile. Bot Mar 33:363-367

Westermeier R, Müller DG, Gómez I, Rivera P, Wenzel H (1994) Population biology of Durvillaea antarctica and Lessonia nigrescens (Phaeophyta) on the rocky shores of southern Chile. Mar Ecol Prog Ser 110:187-194

Weykam G, Gómez I, Wiencke C, Iken K, Klöser (1996) Photosynthetic characteristics and $\mathrm{C}: \mathrm{N}$ ratios of macroalgae from King George Island (Antarctica). J Mar Exp Mar Ecol 204:1-22

Wiencke C, Gómez I, Pakker H, Flores-Moya A, Altamirano M, Hanelt D, Bischof K, Figueroa FL (2000) Impact of UVradiation on viability, photosynthetic characteristics and DNA of brown algal zoospores: implications for depth zonation. Mar Ecol Prog Ser 197:217-229

Yakovleva IM, Dring MJ, Titlyanov EA (1998) Tolerance of North Sea algae to UV and visible radiation. Russ J Plant Physiol 45:54-64

Submitted: June 16, 2003; Accepted: November 27, 2003

Proofs received from author(s): March 26, 2004 